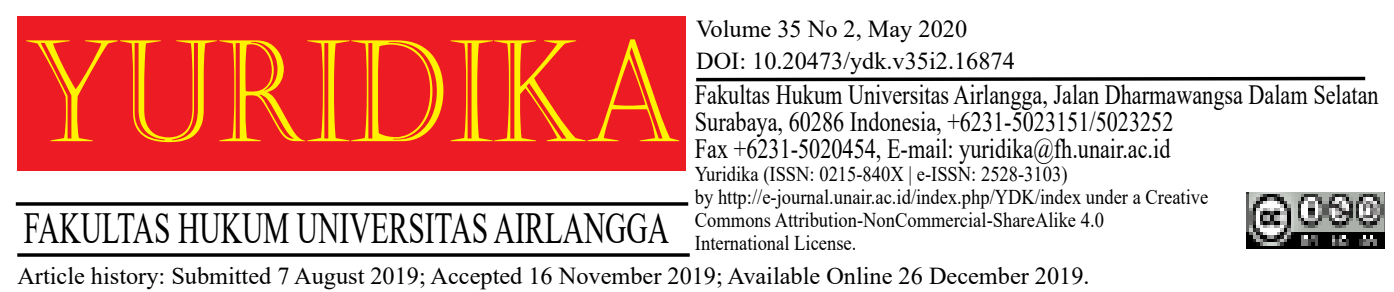

\title{
State-Owned Enterprises Finance from the Perspective of State Funds
}

\author{
Sopian Sitepu \\ ss.partners@yahoo.co.id \\ Sopian and Partners Law Office
}

\begin{abstract}
The existence of State-Owned enterprises (SOE) as one of Indonesia's legal entities, whereby the State owns part of all of the capital of the company has presented several legal issues. The BUMN Act that has become the basis for establishing State-Owned enterprises has become its own independent legal subject and separates itself from the wealth of the State and has adhered to the provisions of the Company Law Act so that the capital that is presented by the State to the corporation remains as the capital of the SOE and not form the State. However, existing legislations regarding State funds places the funds for SOE as being part of the State budget. This ambiguity in the status of BUMN Funds is not only found in legislations but also in two different constitutional court decisions that presents inconsistencies towards law enforcers. This clear distinction is crucial in the practice of law enforcement in Indonesia.

Keywords: BUMN; State-Owned Enterprises; State-Owned Enterprises Capital; State Funds.
\end{abstract}

\section{Introduction}

The consideration considering that Law Number 19 the Year 2003 concerning State-Owned Enterprises, there are three important considerations relating to the existence of BUMN. These considerations are as follows: first, that BUMN is one of the agents of economic activity in the national economy based on economic democracy; secondly, that BUMN has an important role in the operation of the national economy to realize the welfare of society; third, that the implementation of the role of SOEs in the national economy to realize public welfare is not yet optimal. These considerations are philosophical and sociological considerations of the existence of BUMN itself. ${ }^{1}$

\footnotetext{
1 Muhammad Insa Ansari, 'Badan Usaha Milik Negara Dan Kewajiban Pelayanan Umum Pada Sektor Pos State-Owned Enterprises And Public Service Obligations in the Post Sector’ (2018) 8 Jurnal Penelitian Pos dan Informatika.[3].
} 
Normatively the importance of SOEs in the national economic system is also stated in the Explanation of Law Number 19 the Year 2003 concerning State-Owned Enterprises. In Number II General stated as quoted below:

"In the national economic system, SOEs play a role in producing goods and/or services needed to realize the amount of prosperity of the people. The role of BUMN is felt to be increasingly important as a pioneer and/or pioneer in business sectors that are not yet interested in private business. Also, SOEs also have a strategic role as implementing public services, balancing large private forces, and helping to develop small businesses/cooperatives. BUMN is also a significant source of state revenue in the form of various types of taxes, dividends and privatization proceeds".

The implementation of the BUMN role is realized in business activities in almost all economic sectors, such as agriculture, fisheries, plantation, forestry, manufacturing, mining, finance, post and telecommunications, transportation, electricity, industry, and trade, and construction. The explanation as quoted above, shows that there is so much hope from the legislators that SOEs need to take an important role in bringing about the welfare of the people. Also, SOEs are expected to be a pillar of pioneering activities or pioneering activities that the private sector has not yet interested in business activities that are economically unprofitable. Also, the strategic role of SOEs as a public service is an equally important hope. Another role expected based on this explanation is state revenue. The general explanation of Law Number 19 of 2003 concerning State-Owned Enterprises also mentions a number of business activity sectors that indicate the involvement of SOEs in economic activities. As one of the economic actors in the national economy, BUMN has an important meaning in realizing community welfare. In realizing public welfare, SOEs are sometimes assigned by the state to carry out public service obligations. For this reason, there are a number of SOEs assigned by the government, especially those relating to transportation, electricity, oil and gas distribution, and fertilizer supply for farmers. Public service obligations basically and should be carried out by the government as an extension of the state in realizing public welfare. However, public service obligations are sometimes assigned by the government to SOEs. ${ }^{2}$

2 ibid. 
The existence of State-Owned enterprises (SOE) as one of Indonesia's legal entities whereby the State owns part of all of the capital of the company has presented several legal issues. The BUMN Act that has become the basis for establishing StateOwned enterprises has become its own independent legal subject and separates itself from the wealth of the State and has adhered to the provisions of the Company Law Act so that the capital that is presented by the State to the corporation remains as the capital of the SOE and not form the State. However, existing legislations regarding State funds places the funds for SOE as being part of State budget. The status of SOE capital, whether or not they may be part of State funds must be clearly defines as it will impact law enforcers and the criminal sanctions involved in claiming for actions that have made a loss for SOE. If SOE finances are included in state finances, all actions against the law or abuse of authority, facilities or opportunities that harm SOE finances are prosecuted based on criminal provisions in the PTPK Act. And vice versa, if SOE finance is not state finance then all actions against the law that harm SOE finances are subject to the provisions of the Criminal Code and the Company Law Act. Based on the background above, the legal issue to be discussed is whether SOE finance is included in state finance?

\section{State finance in the State Finance Act}

State finance in the State Finance Act is all rights and obligations of the state that can be valued in money, as well as everything in the form of money or in the form of goods that can be made owned by the state in connection with the implementation of these rights and obligations. ${ }^{3}$ Based on Article 2 of the Law on State Finance, the scope of state finances referred to in the law covers:

a. The right of the State to obtain taxes, produce and release money, and make loans;

b. The obligation of the State to provide a governmental service and pay the bills from a third party;

c. State income;

d. State expenses;

3 Nanang Yusruni,[et., al] 'Privatisasi Badan Usaha Milik Negara(BUMN), Eksistensi, Dan Kinerja Ekonomi Nasional Dalam Sistem Ekonomi Pasar' (2007) 2 Jurnal Ekonomi \& Bisnis.[74]. 
e. District income;

f. District expenses;

g. State wealth/district wealth that is independently managed or by another party in the form of money, bonds, credit, goods, as well as other rights that can be valued as money, including wealth that is separated to state funds/district funds;

h. Third party wealth that is controlled by the State in executing its governmental functions and/or public interest;

i. Third party wealth that is obtained through the facilities given by the government.

The scope of state finance in Article 2 of the Law on State Finance is very broad because state finance is interpreted as the right to collect taxes, the wealth of other parties controlled by the government in the context of carrying out governmental tasks and/or public interests and the wealth of other parties obtained using facilities provided by the government. The concept of state finance in the State Finance Act which includes the wealth of other parties controlled by the government in the context of carrying out governmental duties and/or public interests and the wealth of other parties obtained by using facilities provided by the government can potentially cause conflicts between the owners of the assets controlled by the government. Control for the purpose of carrying out governmental tasks and/or public interests is not the same as ownership because the control is only related to the use of non-ownership so that the assets of other parties controlled by the government should be carried out in the framework of carrying out governmental tasks and/or public interest and other parties' assets obtained by using governmentprovided facilities is not qualified as part of state finances. The definition of state finance put forward by Jimlah Asshiddiqie is an understanding of state finance in a broad sense because the benchmarks used to determine state finance are related to state revenues and expenditures. There also exists SOE which refers to the scope of state finances in Article 2 of the Law on State Finance as assets that are separated in state/regional companies. In addition to the definition of state finance in the general provisions stipulated in Article 1 and Article 2, in the general explanation the State Finance Law explains the definition and scope of state finances namely: 
"The approach used in formulating State Finance is in terms of objects, subjects, processes, and goals. In terms of objects referred to as State Finance includes all rights and obligations of the state that can be valued in money, including policies and activities in the field of fiscal, monetary and management of separated state assets, as well as everything in the form of money, or in the form of goods that can be used as property the state relates to the implementation of these rights and obligations. From the subject matter, the meaning of State Finance covers all objects as mentioned above which are owned by the state, and/or are controlled by the Central Government, Regional Governments, State/Regional Companies, and other bodies that are related to state finance. In terms of process, State Finance covers the entire set of activities related to the management of objects as mentioned above, starting from the formulation of policies and decision making to accountability. In terms of objectives, State Finance covers all policies, activities and legal relations relating to ownership and/or control of objects as mentioned above in the context of implementing state government. Such a broad sector of State Financial management can be grouped in the sub-sector of fiscal management, the sub-sector of monetary management, and the sub-sector of management of separated state assets".

Based on the general explanation of the Law on State Finance above, the formation of the Law on State Finance does have a view of control over the objects as mentioned above in the framework of the administration of the State as part of state finances. In connection with the control by the state of the wealth of other parties for the interests, it will raise a question about when the other party's wealth is removed from state finances and what are the procedures for removing it from state finances and whether the owner of the wealth has the freedom to at any time to ask for assets controlled by the state governing the government Country. In connection with the provisions on state finances in the State Finance Law, Arifin P. Soeria Atmadja said that the legislators did not understand the difference principles between state finance, regional finance, state and regional company finance and even private finance was also regulated. ${ }^{4}$

Geodhart elaborates that the concept of state finance is all of the legislations that has been established periodically that presents the power for the government to make expenses within a certain period and showcase the tools of payment needed

4 Arifin P. Soeria Atmadja, Keuangan Publik Dalam Perspektif Hukum: Teori, Praktik Dan Kritik (3rd edn, RajaGrafindo Persada 2013).[73-74]. 
for those expenses. ${ }^{5}$ The definition of state finance proposed by Geodhart is the definition of state finance in the normative sense, stating that state finance must be in accordance with the provisions in the law. If by statutory regulations it has been determined what constitutes state revenues and expenditures, then that is state finance. State finance is one of the important aspects in the existence of a country because the state's financial condition will provide a picture of the economic, political, security and social stability of a country. Hernold Ferry Makawimbang stated two parts of the state financial mindset namely: ${ }^{6}$

a. All of the rights and obligations of the State that can be financially values:

1. The right of the State to obtain taxes, produce and release money, and make loans;

2. The obligation of the State to provide a governmental service and pay the bills from a third party;

b. Everything, whether it be in the form of money or not, that can be owned by the State in relation to executing such rights and obligations:

1. State income and expenses;

2. District income and expenses;

3. State wealth/district wealth that is independently managed or by another party in the form of money, bonds, credit, goods, as well as other rights that can be valued as money, including wealth that is separated to state funds/district funds;

4. Third party wealth that is controlled by the State in executing its governmental functions and/or public interest;

5. Third party wealth that is obtained through the facilities given by the government.

The definition of state finance put forward by Hernold Ferry Makawimbang is almost the same as the definition of state finance in the State Finance Act. Otto Ekstein said that state finance is a field that studies the effects of the budget on the economy, especially as a result of achieving economic goals that are the main

5 Alfin Sulaiman, Keuangan Negara Pada BUMN Dalam Perspektif Ilmu Hukum (Alumni 2011).[20].

6 Hernold Ferry Makawimbang, Memahami \& Menghindari Perbuatan Merugikan Hukum Negara Dalam Tindak Pidana Korupsi Dan Pencucian Uang (Thafa Media 2015).[112]. 
growth, justice, and efficiency. ${ }^{7}$ The definition put forward by Otto Ekstein above does not include state revenue even though expenditure and income are a package in state finance. The definition of state finance in the general explanation of the PTPK Act, namely all state assets, in whatever form are separated or not separated including all parts of state assets and all rights and obligations arising from:

a. Being in the place of power, management and responsibility of State authorities, both in the central government and district government;

b. Being in a place of power, management and responsibility of an SOE, a district owned company, foundation, legal body, a corporation that uses State funds, or a corporation that uses third party funds based on the agreement of States.

Arifin P. Soeria Atmadja said that state finance is in terms of accountability by the government, that state finance that must be accounted for by the government is state finance that only comes from the state budget so that what is meant by state finance is finance that comes from the state budget. ${ }^{8}$ The dualism of the definition of state finance, namely the understanding of state finance in a broad sense and the definition of state finance in a narrow sense. The definition of state finance in the broad sense referred to is finance originating from the State Budget, Regional Budget, Finance of State Business Units or state-owned companies and in essence all state assets. While the definition of state finance in the narrow sense is financial that comes from the state budget only. ${ }^{9}$ The definition and scope of state finances contained in the State Finance Act and Explanation of the PTPK Act constitute the true definition of state finance when viewed from the aspect of protecting state finances because the separated state finances will eventually be returned to state finances so that law enforcement officials and the Supreme Audit Agency need

7 Tim BEPEKA, Keuangan Negara Dan Badan Pemeriksa Keuangan (Sekretariat Jenderal, Badan Pemeriksa Keuangan 2010).[13].;Otto Ekstein, Keuangan Negara (Bina Aksana 1981).[48]

8 Eva Herianti, 'Budget Turbulence and Budget Deviation: Do Local Government Have the Ability to Reduce Them?' (2019) 5 Jurnal Tata Kelola dan Akuntabilitas Keuangan Negara <http:// www.jurnal.bpk.go.id/index.php/TAKEN/article/view/285>.[6].

9 Arifin P. Soeria Atmadja, Mekanisme Pertanggungjawaban Keuangan Negara (Gramedia 1986).[49]. 
to provide protection for the separated state finances. ${ }^{10}$ State finance from the perspective of state financial protection must indeed be interpreted as state finance as referred to in the State Finance Law and the PTPK Law because the separation of state finances through equity participation in SOEs is not for the purpose of abolishing state finances but to obtain profits as a source of state revenue.

State finance based on the BPK Act is all rights and obligations of the state that can be valued in money, as well as everything in the form of money or in the form of goods that can be owned by the state in connection with the implementation of these rights and obligations. The definition of state finance in the BPK Act above simplifies the definition of state finance in the State Finance Law and the PTPK Act without removing the essential elements in the State finances that are of a value that can be measured in money. Basically, state finance is the country's rights and obligations that have economic value. According to M. Ichwan, state finance is a quantitative plan of activities (with figures included in the amount of currency), which will be carried out for the future, usually in the coming year. ${ }^{11} \mathrm{M}$. Ichwan's definition of state finances put forward more to the understanding of the State Budget (APBN) so that it does not cover state finances as a whole. The APBN does not contain the entire state assets because the APBN only contains the annual state revenue and expenditure plan. If the state finances are only interpreted by the State Budget, then regional finances are not part of the state finances. Thus, the notion of state finance put forward by M. Ichwan is less precise because it narrows the meaning of state finance.

The understanding of State finances can also be seen from the definition of losses of State finances. The state financial losses based on the State Treasury Law and the BPK Law are shortages of real and definite amounts of money, securities and tangible goods as a result of intentional or negligent unlawful acts. ${ }^{12}$ Based

${ }^{10}$ Asri Agung Putra, 'Tindak Pidana Korupsi Di Bidang Perpajakan' (Universitas Airlangga 2018).[81].

11 W. Riawan Tjandra, Hukum Keuangan Negara (Grasindo 2006).[1-2].

${ }^{12}$ Article 1 paragraph 22 of the State Secretariat Act. 
on the definition of state financial losses in the State Treasury Law and the BPK Law, then by virtue of a contrario State finances are real and definite amounts of money, securities and goods. State finance as a legal substance of state finance can be viewed from the aspect of state finance in the broad sense and state finance in the narrow sense. ${ }^{13}$ State finance in the narrow sense is only aimed at the state revenue and expenditure budget which is determined annually in the form of a law while State finance in the broad sense can be viewed from the approach of formulating the definition of state finance in the explanation of the State Finance Law as follows: ${ }^{14}$

a. From the its object, what is meant by state finance includes all rights and obligations of the state that can be valued in money including policies and activities in the field of fiscal, monetary and management of separated state assets as well as everything in the form of money or in the form of goods that can be made the property of the state in relation to the exercise of these rights and obligations;

b. From its subject, what is meant by state finance is to include all objects as mentioned above are owned by the state, and/or controlled by the central government, regional governments, state/regional companies and other bodies related to state finance;

c. From its process, state finance covers the entire set of activities related to object management as mentioned above starting from policy formulation and decision making to accountability;

d. In terms of objectives, state finance covers all policies, activities and legal relations relating to ownership and/or control of objects as mentioned above in the context of administering state government.

Based on the definition of state finance in the narrow and broad sense above, state finance is all rights and obligations of the state that can be valued in money based on the right to collect, hold or control by the central government, regional governments, stat/regional companies and other entities that are relating to the administration of government. State finance is not only related to the state revenue and expenditure plan because state finance includes money or goods that have economic value that has been owned or controlled by the central government, regional governments, state/regional companies and other bodies related to government administration. Furthermore, Muhammad Djafar Saidi stated that State

\footnotetext{
${ }^{13}$ Muhammad Djafar Saidi, Hukum Keuangan Negara (Rajagrafindo Persada 2013).[11].

14 ibid.[12].
} 
finance in a broad sense includes an inseparable unity, namely the state budget of revenue and expenditure, the budget of regional income and expenditure, state finance in SOE and District owned companies. ${ }^{15}$ Based on the scope of the State's finances stated by Muhammad Djafar Saidi above, the State should be related to the State's finances should be interpreted as implementing executive, legislative, judicial authority as well as State institutions and other institutions that exercise authority based on legislation.

The definition of state finance in the State Finance Law and other laws and regulations is the definition of state finance in a broad sense. The purpose of regulating the State's finances in the broad sense in the Law on State Finance and other laws and regulations is to prevent multi-interpretation in the implementation of the budget, prevent state financial losses as a result of weaknesses in the formulation of laws and clarify the process of law enforcement in the event of maladministration in management state finances. ${ }^{16}$ In principle, the purpose of regulating the State's finances in the broad sense in the Law on State Finances and other laws and regulations is the affirmation of law-forming institutions regarding the importance of State finance in the existence of the Indonesian State so that the protection of State finances must be carried out since the legislation.

\section{SOE Finances are not State Finances}

The regulation of state finances in the broadest sense elaborated in the Law on State Finance and other laws and regulations has a good purpose but has led to debates relating to state assets separated in SOEs, especially in the form of state-owned companies. SOE as referred to in the SOE Act is a business entity whose entire or most of its capital is owned by the state through direct participation from the separated state assets. The discussion on SOE as one of the problems and means for the eradication of corruption in Indonesia is never-ending, even though there have been many court

\footnotetext{
15 ibid.

16 Rahayu Hartini, BUMN Persero, Konsep Keuangan Negara Dan Hukum Kepailitan Di Indonesia (Setara Press 2017).[92].
} 
decisions on corruption cases involving SOE. The existence of several court decisions that has indirectly solidifies the finances of SOE as State funds cannot be used as the only basis to justify SOE finance as State funds. The fundamental question still remains based on the issue of capital from the State within SOE, and whether or not this is still part of State funds. This question was first raised under the fact that SOE are indeed limited liability companies that have its own wealth or wealth that is separated form the establishers of the company, through providing capital in the establishment of the company. State assets separated by capital participation in the establishment of SOEs are very important to be clearly defined because they relate to the accountability of State financial management. If capital participation in SOEs is part of the State finances, actions which are detrimental to SOEs' finances may be subject to criminal provisions as referred to in Article 2 and Article 3 of the PTPK Act. Vice versa, if capital participation in SOEs does not constitute State finance or in other words becomes SOE finance, actions that harm SOE finances cannot be subject to criminal provisions as referred to in Article 2 and Article 3 of the PTPK Act. In connection with the status of SOE wealth, there are two different opinions, namely SOE wealth is State finance and SOE wealth is not State finance but SOE finance in its position as a limited liability company.

Muhammad Djafar Saidi elaborates that the existence of State wealth that is separated as a form of State capital participation which has evolved in principle with the existence of constitutional court decision number 48/PUU-XI/2013 and constitutional court decision Number 62/PUU-XI/2013 that, in principle, states that State wealth is separated from capital participation in SOE is indeed State funds. ${ }^{17}$ The Constitutional Court in the Decision of the Constitutional Court Number 48/ PUU-XI/2013 in its legal considerations states that the State-Owned Legal Entity of Higher Education (BHMN Ltd, SOE and District Owned Enterprises or other names that is currently executing a constitutional mandate as an extension of the powers of the State which functions as a tool to improve public education and public welfare,

${ }^{17}$ Muhammad Djafar Saidi (n 13).[51]. 
the capital of the legal entity is partly or wholly derived from the State's finances so that the legal entity cannot be fully considered as a private legal entity. Whereas in constitutional court decision Number 62/PUU-XI/2019, the constitutional court in its legal considerations states that the separation of State wealth from a purely transactional perspective is not a transaction that diverts a right as to create a legal impact $^{18}$ which does not allow the diversion of the right of the State in SOE or District-owned enterprises. Thus, the wealth of the State that is separated is still considered as State finance that may or may not be transformed to become the initial capital of SOE or District-owned enterprises, its management will adhere to the business judgement rules. However, the separation of State wealth does not directly mean that the wealth of SOE or District-Owned Enterprises (hereinafter "DOE") to be free of State finances.

The decisions of the corruption court as well as the Supreme Court in regards to corruption cases within SOE aligns with the Constitutional Court Decision Number 48/PUU-XI/2013 and the constitutional court decisions Number 62/PUU$\mathrm{XI} / 2013$ which in law and law enforcement relates to the disparities of managing SOE funds, law enforcers (police, judges, KPK and the Supreme Court has agreed that SOE funds fall under State funds. The criminal case decisions that have already been declared to have legally binding powers as well as constitutional court decision Number 48/PUU-XI/2013 and constitutional court decision number 62/ PUU-XI/2013 in reality cannot stop the debate regarding the status of SOE finance as State funds. The example in managing the case against former CEO of Pertamina who was charged with the criminal act of corruption in accordance with Article 2 and Article 3 of PTPK Act relates to the business transactions of Pertamina. The defendant and his lawyers presented a counter argument towards the case, stating that it is not a corruption case because the funds of SOE are not State funds and the loss in such business transactions are mere business risks.

18 Titon Slamet Kurnia, "'Peradilan Konstitusional” Oleh Mahkamah Agung Melalui Mekanisme Pengujian Konkret’ (2019) 16 Jurnal Konstitusi <http://ejournal.mahkamahkonstitusi. go.id/index.php/jk/article/view/1614>.[63]. 
Basically, the Constitutional Court does not always state that SOE finances or assets are the State's finances because the Constitutional Court in decision number 77/PUU-IX/2011 dated 25 September 2012 principally, in their legal considerations, states that SOE assets are assets that are separate from State assets including debts and with the enactment of the SOE Act and the Company Law Act, SOE Bank Credits are no longer State Credits, the settlement of which is done by PUPN, but can be settled by the management of each SOE Bank based on sound principles and as a limited liability company, SOE assets have been separated from State wealth and management or company management has complied with the Indonesian Company Law Act. Law Number 49 Prp. Year 1960 concerning the Committee on State Credit Affairs (State Gazette of the Republic of Indonesia 1960 Number 156 Additional State Gazette of the Republic of Indonesia Number 2104) hereinafter referred to as the PUPN Act in Article 8 stipulates what is meant by State Credits or debt to the State is the amount of money that must be paid to the State or Agencies that are either directly or indirectly controlled by the State based on a regulation, agreement or any cause. Furthermore, in the Elucidation of Article 8 of the PUPN Act, it is determined that the state receivables are meant to be directly owed to the State and therefore must be paid to the Central Government or Regional Government and to the material which are generally assets and capital partially or wholly owned by the State, for example State-owned Banks, Limited liability companies, SOE, Supplies and support foundations, foundations regulating food, etc.

Tax debts are also state credit, but which are individually administered under the State Tax Withholding Law. Based on the provisions in Article 8 of the PUPN Act, what is meant by State credit is state receivables and accounts receivable that are either directly or indirectly controlled by the state in this case including loans from SOE Banks that are directly or indirectly controlled by the state.

The constitutional court in decision number 77/PUU-IX/2011 in principle has stated that the regulations for SOE credits is State credits, contradicts the constitution under the following fundamental reasons:

a. SOE are business entities that have assets separate from state assets, so that the 
authority to manage wealth, business, including the settlement of SOE debts is subject to limited liability company Act.

b. The Law of State Treasury has changed the definition of State credits, that is, state receivables are the amount of money that must be paid to the Central Government and/or the rights of the Central Government that can be valued in cash as a result of agreements or other consequences based on applicable laws or other legal results, so that SOE or state receivables have been removed from the scope of state credit.

c. The rules regulating the handing over of SOE Banks credits are to be diverted and handed-over to the PUPN. This has cause differential treatment between the debtors on SOE Banks and debtors of other banks which are not SOE Banks. Thus violating the constitutional principles engraved in Article 28D Paragraph (1) of the 1945 Constitution.

There are 2 (two) important points in the consideration of the Constitutional Court Decision above, namely SOE is a business entity that has assets separate from State assets, so that the authority to manage wealth, business, including the settlement of BUMN debt is subject to limited liability company Act and the State Treasury Act has removing state or state receivables from the scope of State credits. The Constitutional Court should also be consistent in its legal considerations, namely if the separation of state assets means that the SOE has authority over these assets in accordance with the SOE Act and the Company Act, and the separation of SOE receivables from SOEs should also apply in the separation of SOEs and State finances. Decision of the Constitutional Court Number 77/PUU-IX/2011 dated 25 September 2012 aligns with the Supreme Court Advisory Opinion number WKMA/ Yud /20/VIII/2006 dated August 16, 2006 which in essence states SOE finance is not State finance. The Supreme Court issued an Advisory Opinion Number WKMA/ Yud/20/VIII/2006 dated August 16, 2006 to answer the Minister of Finance's Letter Number S-324/MK.01/2016 dated July 262006 but the Supreme Court as the executor of judicial power is not committed in implementing what has been stipulated in the advisory opinion because the Supreme Court and judges under 
the Supreme Court in creating decisions still view BUMN finance as State finance so that in the event of SOE losses, SOE organs have the potential to be charged and prosecuted for corruption as referred to in Articles 2 and 3 of the PTPK Law . To equate SOE finances as state finances will have implications for impeded SOE business management activities. ${ }^{19}$ The threat of criminal charges for corruptive acts of the organs of SOE has hindered SOE from taking creative action the development of its business. Constitutional court decision Number 77/PUU-IX/2011 dated 25 September 2012, corruption even in cases within the Supreme Court regarding SOE corruption aligns with constitutional court decision number 48/PUU-XI/2013 and constitutional court decision Number 62/PUU-XI/2013 is a form of inconsistency in the practice of the constitutional court and presents confusion regarding the states of the wealth or finances of SOE.

The Constitutional Court applies a double standard in assessing SOE's financial status or wealth relating to SOE debts, SOE assets are assets separated from State assets including its debts and with the enactment of SOE Act and PT Act, SOE Bank receivables are no longer state receivables whereas for the purpose of examining cases of criminal acts of corruption as referred to in the PTPK Act, the Constitutional Court is of the opinion that SOEs' finances or assets are the State's finances. The existence of two Constitutional Court decisions that are contradictory with regard to SOE's financial status or wealth proves that there is something wrong in the regulation and understanding of State assets separated in SOEs.

There are two possibilities for the Constitutional Court to have two different decisions relating to the status of state assets separated in SOEs, namely the Decision of the Constitutional Court Number 77/PUU-IX/2011 creates an objective mindset of understading state financial law while the Decision of the Constitutional Court Number 48/PUU-XI/2013 and Constitutional Court Decision Number 62/PUU$\mathrm{XI} / 2013$ are decided based on subjectivity because the testing of the law is related to handling cases of corruption so that if the Constitutional Court is of the same

\footnotetext{
${ }^{19}$ Refly Harun, BUMN Dalam Sudut Pandang Tata Negara, Privatisasi, Holdingisasi, Kontrol Dan Pengawasan (Balai Pustaka 2019).[53].
} 
opinion as the Decision of the Constitutional Court Number 77/PUU-IX/2011 there is a concern that the Constitutional Court will lose the trust of the people (who really hate corruption) because it is considered not to support efforts to prevent and eradicate corruption. Regardless of the reason for the Constitutional Court to make two different decisions, these Constitutional Court's decision has been used as a criminal cases based on the provisions regarding the existence of Criminal Acts on PTPK against parties deemed to cause losses to state finances because it causes harm to SOEs. Even the Constitutional Court Decision Number 48/PUU-XI/2013 and the Constitutional Court Decision Number 62/PUU-XI/2013 have been used as a basis for applying criminal provisions in the PTPK Act against criminal offenses that have been regulated in separate laws such as banking crime at a state-owned bank.

Decisions of criminal cases that have permanent legal force or Constitutional Court Decision Number 48/PUU-XI/2013 and Constitutional Court Decision Number 62/PUU-XI/2013 do not resolve the issue of whether or not SOE's financial status are State's finance because in the related legislation there are still conflicting norms between specific laws, namely the SOE Act. Article 1 number 1 of the SOE Act stipulates that an SOE is a business entity whose entire or most of its capital is owned by the state through direct participation from separated state assets. SOEs whose shares are partly owned by the private sector will cause legal problems if the assets of SOEs are considered as State finance. Limits to determine where SOE assets are included in state finance and SOE assets that are not included in state finance are very biased and difficult to determine because the acquisition of SOE assets in the form of goods does not pay attention to the source of money used to obtain the goods. Furthermore, Article 1 number 10 of the SOE Act determines the separated State assets are state assets originating from the State Budget to be used as state capital participation in the Limited Liability Company and/or Public Corporation and other companies.

The affirmation regarding the separation of state assets through equity participation in SOEs is regulated in Article 4 paragraph (1) of the SOE act which determines that SOE capital is and originates from separated state assets. 
Furthermore, in the elucidation of Article 4 paragraph (1) the SOE Law determines what is meant by being separated is the separation of state assets from the State Revenue and Expenditure Budget to be used as state capital participation in SOEs for further development and management is no longer based on the State Revenue and Expenditure Budget system, however guidance and management are based on sound company principles. With reference to the explanation of Article 4 paragraph (1) of the SOE Act, it is very clear and firm that SOE finance is not a State finance because its management is different from the management of State finance. SOE financial management is not subject to the provisions of the State Finance Law or the State Treasury Law but is subject to corporate principles as stipulated in the Company Act and the SOE Act.

The existence of constitutional court decision number 77/PUU-IX/2011 aligns with the provisions within the SOE Act because the management of SOE funds must be differentiated from the management of State funds. There is a fundamental difference in the management of state finances and SOE finances, namely in managing state finances if there is a loss of state finances, it is almost certain the loss of the State is due to criminal acts of corruption while SOE financial losses are not always due to errors from the Directors or other SOE organs because in SOE activities there is a business risk which is very likely to be a loss for SOEs in every business transaction conducted. If SOE finances are equated with State finance, innovation in developing SOEs to achieve the goals of establishing or forming SOEs is very difficult to achieve because there are concerns for SOE organs over the threat of criminal sanctions for corruption. SOEs are obliged to innovate in their business activities because SOEs will compete with the private sector in which every business actor will always create innovations for business development. This is the main reason why equating SOE finances with SOE finances will hamper the development of SOEs.

In order to maintain their existence and competitiveness with the private sector. SOEs are obliged to make innovations to develop business activities, but there is no guarantee that innovations will always bring benefits or cause minimal 
harm to SOEs. The demand to innovate in the shadow of the threat of criminal sanctions on corruption is an unfair condition for SOE organs. The State should provide legal protection for organs of SOEs in creating business innovations by maintaining healthy company management as a guarantee of good management of State wealth that is separated and can be held accountable. These healthy corporate principles are asserted in the explanation to Article 5 paragraph (2) of the SOE Act that determines directions of SOE organs that is delegated to conduct management under a certain set of rules which applies to SOE and holds near the application of the principles of good corporate governance, which are the following:

a. Transparency namely openness in carrying out the decision making process and openness in disclosing discussion materials and relevant information about the company;

b. Independence which are the conditions where the company is professionally managed without conflict of interest and influence/pressure from any party that is not in accordance with the laws and regulations and healthy corporate principles;

c. Accountability which is exempted by clear functions, clear execution and accountability of the organs as to result is effective management;

d. Responsibility namely compliance in company management with the laws and regulations and healthy corporate principles;

e. Fairness, namely compliance in the management of the company with existing laws and regulations and healthy corporate principles.

Protection of State interests in SOE financial management must not always involve a criminal approach as to not force SOE finance to be included as State finance. As a result separating the criminal sanctions within PTPK Act that can be used to protect State wealth that is separated from SOE finances, due to the fact that SOE Act and Company Law Act has regulated the oversight mechanism that must be invoked to SOE. Oversight should be done by the Commissary and the Supervisory Board that has been established by the Minister. This supervision is done by authorities within the corporation as well as the auditing committee established by the Commissary and the Supervisory Board. Revisions of company fiscal reports are conducted by an external auditor that is determined by the annual shareholder meetings for companies and by the Minister. Further, regulatory checks are conducted by the BPK. The supervision of SOE financial management by BPK cannot be used as a reason to justify SOE finance being the State finance 
because the supervision is only to ensure SOE financial management is carried out properly so that there is no reduction in the profits derived by the State from SOE business activities.

Supervision of SOE financial management is very strict so there are no compelling reasons to impose SOE finances the same as State finances. Any loss in SOE financial management due to SOE organ error must be personally and jointly accountable. Commentaries to Article 71 paragraph (1) of the SOE Act determines that financial audits of SOEs are intended to obtain the auditor's opinion regarding the reasonableness of the financial statements and the annual calculation of the company concerned. The auditor's opinion on the financial statements and annual calculations referred to is required by shareholders/Ministers, among others, in the context of granting acquit et decharge to the Directors and Commissioners/Board of Trustees of the company. Provisions in the elucidation of Article 71 paragraph (1) of the SOE Act are closely related to the provisions in Article 97 and Article 114 of the Company Act. Article 97 of the Company Act stipulates that the Board of Directors is responsible for the management of the Company which is carried out in good faith and with full responsibility and as a consequence each member of the Board of Directors is personally responsible for the Company's losses if the person concerned is guilty or fails to carry out his duties. Furthermore, in Article 114 of the Company Act regulates the provisions of the Board of Commissioners responsible for the supervision of the Company which is carried out in good faith, prudence, and is responsible for carrying out supervisory duties and providing advice to the Directors and Each member of the Board of Commissioners is personally responsible for the Company's losses if the person is guilty or negligent in carrying out their duties. With several mechanisms to supervise the financial management of SOE as well as the accountability of the Direction and Commissioner in managing the finance of SOE, when a loss occurs there exists a no particular need to apply state financial management to SOE financial management so that the wealth of the State is separated from SOE wealth. Due to the fact that SOE wealth cannot be equated with State wealth. 
The State should have given legal certainty not only for the things that will directly benefit the State. Experts, whether it be law enforcers or the State, have not voiced their rejection of separating State credit with SOE credits due to the fact that such separation is deemed beneficial for the State. If SOE finance is considered as State finance, SOE credits and debts must be considered as State debt so that in the event that SOE debt is due, the State has an obligation to make payments on the SOE debt. Regarding SOE debt repayment obligations, the State states that it has no obligation to pay because SOEs have separate assets from the State so that the State's liability is limited to paid-up capital in accordance with Company Act. This is a form of state inconsistency in SOE finance because the State and law enforcement authorities interpret State finances in accordance with the interests and benefits of the State

The thought of SOEs' finances as state finances is contradictory to the rights of other shareholders in the case that the State is not the sole shareholder in SOEs. The majority share ownership by the State in an SOE cannot be used as a basis for stating SOE finances are State finance. If SOE finances are State finance, then private shares that are shareholders are also considered as State property. The act of taking the rights of other shareholders into the State's assets constitutes an act against the law that indicates fraud or embezzlement. The argument of Anwarudin Sulistiyono ${ }^{20}$ which states that State finance is all State wealth that can be valued with money used to realize the welfare and prosperity of the people as a basis for qualifying the finances of SOEs and their subsidiaries as State finance is the same argument with the principle of legal fiction that everyone is considered to know the law.

\section{Concept of State Finance in the Indonesian Legal System}

If the concept of state finance is used in the Indonesian legal system, then the entire collaboration between the government and the private sector in infrastructure development that uses the building or delivery system is not limited to physical

\footnotetext{
${ }^{20}$ Anwarudin Sulistiyono, 'Konsep Kekayaan Negara Yang Dipisahkan Dalam Perspektif Pemberantasan Tindak Pidana Korupsi’ (Universitas Airlangga 2019).[334-335].
} 
buildings including the income derived from the use of such infrastructure must be considered as state finance. In fact, the State has buildings and infrastructure facilities that were built, but the results of the utilization of the State infrastructure are left to the private sector for a certain period of time. When referring to the concept of state finances proposed by Anwarudin Sulistiyono, these actions constitute acts which are detrimental to the State's finances but law enforcement officials never declare them to be criminal acts of corruption. Thus, the concept of the State finances regulated in the State Finance Law and the PTPK Act are subject to restrictions set out in the SOE Law and the Company Act as more specific rules regarding SOEs and corporate legal entities. The habit of law enforcement officers who commit acts that violate special rules in other laws with protection behind the PTPK Act must be stopped because it damages the criminal law order in Indonesia. As an example of banking crime which should be prosecuted based on criminal provisions in the law governing banks are required to use the PTPK Act even though Article 14 of the PTPK Act has explicitly regulated the use of criminal sanctions in the PTPK Act.

Furthermore, as a legal entity, limited liability companies are an independent legal personality that is strictly separated in executing the rights of obligations of its managers (separate entity separate liability). ${ }^{21}$ Equity participation by shareholders in a company is established or transformed into shares that have an equivalent value to the amount of capital deposited in the company. Equity participation in a company can be simply interpreted as an act of transferring ownership or control of personal wealth to a new legal subject (the company). With the transfer of ownership or control over personal wealth to the new legal subject (the company), the shareholder does not have any power over the assets of a company even though he is domiciled as a shareholder.

The principle of transfer of ownership or control over personal wealth to new legal subjects (companies) also applies to companies in the form of SOEs so that with the participation of capital by the State in SOEs that are transformed into

\footnotetext{
${ }^{21}$ Ricardo Simanjuntak, Esensi Pembuktian Sederhana Dalam Kepailitan (Pusat Pengkajian Hukum 2005).[6].
} 
shares, SOE finance is not included in State finance. SOE as a legal entity has its own assets that are separated from the management's assets and founder's wealth. ${ }^{22}$ Legally, the separation of management and founders' wealth from the assets of a company (SOE) has legal consequences, namely that the SOE founder has no right to the assets that have been transferred to SOE assets. State assets in SOE are not for assets separated in SOE but shares and the right to obtain SOE profit sharing. Thus, what is part of the State's finances in the participation of State capital in SOEs is the State's shares in SOEs and the right to obtain SOE profit sharing so that SOEs should not be part of the State's finances.

In addition to the aforementioned arguments, law enforcement officials are inconsistent in law enforcement practices relating to SOE finances as State finance. The inconsistency of the law enforcement apparatus occurs in the confiscation or seizure of BUMN assets in the form of money or other assets. For example in blocking a personal account and moving money in the amount of Rp.44,000,000,000 from an account owned by PT NK to the KPK holding account. ${ }^{23}$ Confiscation of money and goods belonging to the State and/or controlled by the State is prohibited based on the provisions of Article 50 of the State Treasury Law. The prohibition of confiscation of money and property belonging to the State and/or which is controlled by the State immediately applies to seizure. The prohibition of confiscation in Article 50 of the State Treasury Law applies to anyone, including law enforcement officials. If law enforcement officials agree that SOE finance is state finance, confiscation and seizure of SOE finances is an act contrary to Article 50 of the State Treasury Law so that it cannot be legally justified. Thus, law enforcement officials and judges should not be able to confiscate and confiscate SOE assets or assets from corruption cases. Confiscation or seizure of SOE assets is a denial of SOEs' finances as state finances.

\footnotetext{
${ }^{22}$ Gatot Supramono, BUMN Ditinjau Dari Segi Hukum Perdata (Rineke Cipta 2016).[185].

${ }^{23}$ Julian, 'KPK Blokir Rekening PT Ndya Karya Dan Sita Aset PT Tuah Sejati' (Pos Kota News, 2018) <https://poskotanews.com/2018/04/14/kpk-blokir-rekening-pt-nindya-karya-dan-sitaaset-pt-tuah-sejati/> accessed 15 March 2019.
} 
In fact, law enforcement officers continue to confiscate and even seize assets belonging to SOEs by ignoring the provisions of Article 50 of the State Treasury Law and the argumentation of Article 50 of the State Treasury Law does not apply to confiscation of SOE assets. On a contrario basis, if the provisions of Article 50 of the State Treasury Law are deemed invalid in the confiscation of SOE's assets, SOE's finance is not State's finance so SOE's assets can be subject to confiscation and seizure. The existence of two different treatments regarding SOE finances is contrary to legal certainty which is highly upheld in the enforcement of criminal law and the legislative body should form legislation that confirms the financial status and status of SOEs. Should the confiscation and seizure of the assets of the SOE be carried out, legally the SOE's finances must be deemed not State finance.

SOE finance is not a State finance aligns with the spirit of criminal punishment of SOEs in corruption in the context of preventing and eradicating corruption. Criminal sanctions against SOEs in corruption can be in the form of criminal fines and payment of replacement money. If the SOE does not pay criminal penalties and the obligation to pay substitute money, the public prosecutor as the executor of the court's ruling can seize the assets of SOEs because the prohibition in Article 50 of the Law on State Treasury does not apply to SOE finances. Thus based on aspects of criminal punishment of SOEs and Article 50 of the State Treasury Law, SOE finance is not State finance. SOE finance rather than state finance will rule out the existence of Article 50 of the State Treasury Law so that it can be used as a basis for convicting SOEs in corruption.

\section{Conclusion}

Based on the discussion above, SOE finance is not State finance as there exists a separation of wealth and establishment from the capital of a certain company (SOE), which brings forth the legal consequence whereby the founder of an SOE does not have the right over the wealth that has been handed over as the wealth of the SOE. State funds within SOE does not originate from the wealth that is separated from the SOE, but exists from the shares and rights to obtain part of an 
SOEs revenue. Thus, what is part of the State's finances in the participation of State capital in SOEs is the State's shares in SOEs and the right to obtain BUMN profit sharing so that SOEs should not be part of the State's finances. In addition, law enforcement officials are inconsistent in law enforcement practices relating to SOE finances as State finance. Confiscation of money and goods belonging to the State and/or controlled by the State is prohibited based on the provisions of Article 50 of the State Treasury Law. The prohibition to confiscate money and assets of the State and or is controlled by the State also applies in cases of seizure. The prohibition of confiscation in Article 50 of the Law on the State Treasury applies to anyone including law enforcement officials, but in fact law enforcement officials seize and even seize state property so that confiscation and seizure is contrary to Article 50 of the State Treasury Law. With the existence of the confiscation of SOE assets, its further strengthens the argument that SOE finance is not State funds.

\section{Bibliography}

Alfin Sulaiman, Keuangan Negara Pada BUMN Dalam Perspektif Ilmu Hukum (Alumni 2011).

Anwarudin Sulistiyono, 'Konsep Kekayaan Negara Yang Dipisahkan Dalam Perspektif Pemberantasan Tindak Pidana Korupsi' (Universitas Airlangga 2019).

Arifin P. Soeria Atmadja, Mekanisme Pertanggungjawaban Keuangan Negara (Gramedia 1986).

—_, Keuangan Publik Dalam Perspektif Hukum: Teori, Praktik Dan Kritik (3rd edn, RajaGrafindo Persada 2013).

Asri Agung Putra, ‘Tindak Pidana Korupsi Di Bidang Perpajakan' (Universitas Airlangga 2018).

Eva Herianti, 'Budget Turbulence and Budget Deviation: Do Local Government Have the Ability to Reduce Them?' (2019) 5 Jurnal Tata Kelola dan Akuntabilitas Keuangan Negara <http://www.jurnal.bpk.go.id/index.php/ TAKEN/article/view/285>.

Gatot Supramono, BUMN Ditinjau Dari Segi Hukum Perdata (Rineke Cipta 2016). 
Hernold Ferry Makawimbang, Memahami \& Menghindari Perbuatan Merugikan Hukum Negara Dalam Tindak Pidana Korupsi Dan Pencucian Uang (Thafa Media 2015).

Julian, 'KPK Blokir Rekening PT Ndya Karya Dan Sita Aset PT Tuah Sejati' (Pos Kota News, 2018) <https://poskotanews.com/2018/04/14/kpk-blokirrekening-pt-nindya-karya-dan-sita-aset-pt-tuah-sejati/> accessed 15 March 2019.

Muhammad Djafar Saidi, Hukum Keuangan Negara (Rajagrafindo Persada 2013).

Muhammad Insa Ansari, 'Badan Usaha Milik Negara Dan Kewajiban Pelayanan Umum Pada Sektor Pos State-Owned Enterprises And Public Service Obligations in the Post Sector' (2018) 8 Jurnal Penelitian Pos dan Informatika.

Nanang Yusruni,[et.,al], 'Privatisasi Badan Usaha Milik Negara(BUMN), Eksistensi, Dan Kinerja Ekonomi Nasional Dalam Sistem Ekonomi Pasar' (2007) 2 Jurnal Ekonomi \& Bisnis.

Otto Ekstein, Keuangan Negara (Bina Aksana 1981).

Rahayu Hartini, BUMN Persero, Konsep Keuangan Negara Dan Hukum Kepailitan Di Indonesia (Setara Press 2017).

Refly Harun, BUMN Dalam Sudut Pandang Tata Negara, Privatisasi, Holdingisasi, Kontrol Dan Pengawasan (Balai Pustaka 2019).

Ricardo Simanjuntak, Esensi Pembuktian Sederhana Dalam Kepailitan (Pusat Pengkajian Hukum 2005).

Tim BEPEKA, Keuangan Negara Dan Badan Pemeriksa Keuangan (Sekretariat Jenderal, Badan Pemeriksa Keuangan 2010).

Titon Slamet Kurnia, "“Peradilan Konstitusional” Oleh Mahkamah Agung Melalui Mekanisme Pengujian Konkret' (2019) 16 Jurnal Konstitusi <http://ejournal. mahkamahkonstitusi.go.id/index.php/jk/article/view/1614>.

W. Riawan Tjandra, Hukum Keuangan Negara (Grasindo 2006).

HOW TO CITE: Sopian Sitepu, 'State-Owned Enterprises Finance from the Perspective of State Funds' (2020) 35 Yuridika. 
--This page is intentionally left blank-- 